\title{
Effect of Cyclop-Eeze on Growth and Survival of SHG (Swollen Hindgut Syndrome) Infected Penaeus monodon (Fabricius, 1798) Postlarvae under Two Different Stocking Densities
}

\author{
Shailender . $\mathrm{M}^{1}$, Suresh Babu. $\mathrm{Ch}^{2}$, Srikanth, ${ }^{1}$, Krishna P.V ${ }^{2}$, Jayagopal. $\mathrm{P}^{1}$ \\ ${ }^{I}$ Rajiv Gandhi Centre for Aquaculture (RGCA), DTSP, Kodiyaghat, South Andaman, India. \\ 2,-Acharya Nagarjuna University, Nagarjuna Nagar, India.
}

\begin{abstract}
In recent years, the diseases of shrimp slowed down the development of shrimp culture. Swollen hind gut syndrome (SHG) of tiger shrimp, Penaeus monodon postlarvae is common problem in shrimp hatcheries. Post larvae infected with SHG are generally rejected by the hatcheries and farmers, as stocking of SHG seeds or postlarvae are supposed to cause several problems such as size variation, white fecal disease. Loose shell syndrome etc., resulting is severe loss in form production and earning. In the present study an attempt carried to culture the giant tiger shrimp, P.monodon by using post larvae having swollen hindgut syndrome (SHG). In the present study an attempt has been made to culture the SHG infected post larvae of giant tiger shrimp, Penaeus monodon in six ponds each with 0.5 ha near Karlapalem village of Guntur district in Andhra Pradesh, India. In 3 ponds the seeds were stocked in high stocking density $\left(18 / \mathrm{m}^{2}\right)$ and remaining 3 ponds in low stoking density $\left(9 / \mathrm{m}^{2}\right)$. In both the cases, the Cyclop-eeze feed was mixed with Godrej (Godrej Agro Vet -Vijayawada) feed and provided to the seeds and survival was calculated and compared. The salinity of the ten ponds was ranging between 12 to 28 ppt and pH was 7.8 to 8.4. Minimum 3.6 ppm dissolved oxygen and maximum $5.5 \mathrm{ppm}$ was recorded during the culture period. The temperature was ranging between 26 to $31^{\circ} \mathrm{C}$ and the transparency was 35 to $55 \mathrm{~cm}$. Harvesting was done in low density ponds (A1, A2 and A3) at DOC 140 and high density ponds (B1, B2 and B3)) it was harvested at DOC (Days of culture) 170. Average body weights of the low density ponds were $40.5 \mathrm{~g}$ and high density ponds were $32.6 \mathrm{~g}$. Highest survival (82\%) was recorded in low density ponds and the lowest survival was $(64 \%)$ recorded in high density ponds. Maximum production was reported in low density ponds $(1,494 \mathrm{Kg} / 40.5 \mathrm{~g} / 140 \mathrm{Doc})$ and minimum production was observed in high density ponds $(1,878 \mathrm{~kg} / 32.6 \mathrm{~g} / 170 \mathrm{Doc})$. The maximum amount of feed was consumed by the shrimps in high density ponds $(3474 \mathrm{~kg}$ ) and minimum was in low density ponds $(1973 \mathrm{~kg}$ ). So the FCR (Food conversion ratio) for low density ponds were 1.32 and high density ponds were 1.85 . The net profit obtained from the shrimps in high density ponds is Rs.57, 691 and net profit obtained from low density ponds is $R$ s. 2, 15,300. The results of the present study showed that there is significant difference $(P<0.05)$ in growth and survival and FCR between two stocking densities of the SHG infected postlarvae. Present study revealed that high profit in the shrimp farming was obtained by the optimum or low $\left(8-10 \mathrm{Pl}\right.$ 's/ $\left.\mathrm{M}^{-2}\right)$ stocking density. Above results revealed that the effect of the SHG infected P.monodon postlarvae can be cultured in low stocking densities and harvested as similar to the normal seed provided the best farm management practices are followed by the shrimp farmer. To get better profit, proper nursery stocking, feeding with Cyclop-Eeze, proper water quality management and feed management is crucial.
\end{abstract}

Key words: Penaeus monodon, Cyclop eeze feed, FCR, stocking densities, survival and profit

\section{Introduction}

In India, shrimp culture has grown by leaps and bounds and the industry generated huge revenue in terms of foreign exchange, lot of employment and uplifted the living standards of many people involved directly or indirectly with the industry and reduction of over exploitation of natural resources and food security in tropical and sub-tropical regions (Ramanathan et al., 2005). In general, the knowledge on suitable feeds which support on growth is lacking. It would be highly desirable to develop an efficient feed to improve the profitability. In India, at least 10 potential Penaeid species are available for the coastal aquaculture. However, Penaeus monodon is the only one best species cultured and it constitutes about 95 to $99 \%$ of total farmed shrimp production of the country. There is no doubt about the suitability of P.monodon for farming as a candidate species with highest growth rate and high market value. The success of a crop is greatly depends on the quality of seeds for stocked in ponds. Shrimp seed for stocking are mostly procured by the farmers from the commercial shrimp hatcheries. Farmers collect seed samples from hatcheries and get them tested at commercial seed testing or evaluation from PCR laboratories before stocking. These labs rate the seed based on several parameters such as size, appetite, muscle-gut ratio, stress tests, viral tests etc and advice the farmers to either stock or reject the 
seed. One such seed quality parameter is the presence of Swollen Hindgut Syndrome (SHG). Over the last few years, millions of seed affected by Swollen Hindgut Syndrome (SHG) from hatcheries all across the country were rejected by labs and farmers. Swollen Hindgut Syndrome (SHG) is a morphological deformity that tends to occur at later larval (PL) stage, typically after PL-15 and was first reported by Lavilla-Pistogo et al., (2002) in P.monodon postlarvae. SHG mainly affected the hindgut and to some extent, the posterior midgut. Postlarvae infected with SHG show enlargement and distension of the hind gut folds and its junction with the midgut. This abnormality affects the rhythmic movements in the rectal region in the shrimps resulting in difficulty in expelling the faecal pellets (SEAFDCE/AQD, 1994). Aftabuddin and Akter (2011) also reported that unlike WSSV, though SHG does not show mass mortality of P. monodon larvae, it is still considered to be a nascent problem of concern to many shrimp farmers in India. Most SHG infected seeds are healthy in all other respects included the absence of the deadly WSSV, they are still drained causing severe losses to hatchery operations as well as the shrimp aquaculture industry on the whole (Jaganmohan and Prasad, 2010; Jaideep et al., 2011).In India, aquaculture industry is growing at an alarming rate surprising some major hurdles (disease outbreak and pollution) during its development. The higher stocking densities and poor water quality management might be the reasons for disease outbreak. So sustainable shrimp farming is need of time to overcome the above said problem. In the present study cyclop-eeze feed was used from nursery stage to the end of the culture which was compared with different stocking density ponds. Therefore, the present study was selected to examine the growth and survival of SHG infected post larvae by applying Cyclop-Eeze as an additional feed under two different stocking densities was studied.

\section{Materials And Methods}

This experimental study was carried out in farm site located in Karlapalem village. The farm is situated about $20 \mathrm{~km}$ away from Guntur town, Andhra Pradesh, South India. The total area covered is 6.0 ha of which water spread is about 5.5 ha. Totally six ponds, each with a 0.5 ha was selected for this operation. The ponds are rectangular in shape. The culture is semi intensive type and the depth of pond was $1.5 \mathrm{~m}$. The culture was carried out from May to September 2011. Initially all the selected ponds was allowed to dry and splinter to increase the capacity of oxidation of Hydrogen Sulphide $\left(\mathrm{H}_{2} \mathrm{~S} \uparrow\right)$ and to eliminate the fish eggs, crab larvae and other unwanted predators. Then pond bottom was scrapped 3 to $5 \mathrm{~cm}$ by using a tractor blade to avoid top soil. Then the pond bottom was ploughed horizontally and vertically a depth of $30 \mathrm{~cm}$ to remove the obnoxious gases, oxygenate the bottom soil and remove the hydrogen sulphide odor and to increase the fertility. The soil $\mathrm{pH}$ was recorded in the ponds with the help of cone type $\mathrm{pH}$ meter. For increases the availability of nutrients, required amount of lime was applied to neutralize the acid soil, condition of the soil based on the average $\mathrm{pH}$ level of the pond.

Water management is one of the most important practices during the culture period. Indeed, if the PLs are stocked into a pond with poor algal populations, they will become stressed. That not only greatly reduces PL growth, but weakens the animals, making them much more prone to disease and subsequent death. For blooming, the pond is fertilized with inorganic or organic fertilizers. The initial water levels in all ponds were maintained at $120 \mathrm{~cm}$ level. After filling, one day was allowed for sedimentation of turbid particles. After sedimentation process, chlorination was done for all ponds (dosage for 1 ha for every 1 meter water level $/ 500 \mathrm{~kg}$ chlorine). Blooming process was started after $48 \mathrm{hrs}$ of chlorination. The organic fertilizers such as groundnut oil cake, dry cow dung and rice bran powder was flooded overnight and applied the extract to all the ponds. Then water level was maintained to $120 \mathrm{~cm}$ of the ponds and added urea and super phosphate to improve the primary production. Fertilization enhanced the optimal algal bloom in the ponds and the transparency in the ponds ranged from 30 to $35 \mathrm{~cm}$. Along with the present study, the representative samples of 100 infected and normal postlarvae (PL) were placed in mesh hapas of $1 \mathrm{~m} \mathrm{X} 1 \mathrm{~m} \mathrm{X1m} \mathrm{dimensions} \mathrm{for} \mathrm{each} \mathrm{pond} \mathrm{to} \mathrm{assess} \mathrm{the}$ initial survival in ponds as well as to examine the presence of SHG. The postlarvae in both the experimental ponds were fed with Cyclop-Eeze and vitamin $\mathrm{C}$ right from the beginning of the study to improve their immunity and growth. The postlarvae from the hapas were observed for the presence of SHG, 48 hours after stocking. Thereafter, the juveniles were routinely observed to check health status and growth on weekly basis. Water quality parameters for all the ponds were constantly maintained at best possible level with good management practices.

The SHG infected P. monodon (PL-20) seeds were purchased from local hatchery, Bapatla and were transported in oxygenated double layered polythene bags (Cyclop-eeze feed was given along with seeds during packing). The seeds were brought to the farm site and bags were kept in the pond water for some time to adjust the temperature. The nursery area used for seed stocking was usually 5 to $10 \%$ of the total pond area. Due to this less area the Cyclop-eeze feed can easily reach the post larvae. Then the pond water was added slowly into the seed bag to adjust the salinity and $\mathrm{pH}$. During the acclamations time also Cyclop-eeze feed was provided to the infected post larvae. Subsequently the seeds were released slowly into the nursery section. The stocking density per pond was (A1, A2 and A3) 9/m2 (40,000 PLs / pond) and (B1, B2 and B3) 18/ m2 (75,000PLs / pond) respectively. The post larvae after concise period ( 7 days) in the nursery area were released in to grow out 
ponds. After seed stocking in nursery section, the Cyclop-eeze mixed with the feed for every meal. After one weak, the dosage of Cyclop-eeze mix was varied for different densities. In the preset study the following water quality parameters were recorded regularly for all the ponds. The water level was measured by using a standard scale with $\mathrm{cm}$ marking. The water salinity was measured by using a hand refract meter (Erma-Japan). The $\mathrm{pH}$ of the pond water was measured by using electronic $\mathrm{pH}$ pen manufactured by Hanna Instrumental Company, Japan. Water temperature was measured in the pond itself using a standard centigrade thermometer. The dissolved oxygen was estimated by dissolved oxygen meter. Transparency was measured in terms of light penetration using a secchi disc. During the first 3-4 weeks of culture, water exchange is not required. Water was exchanged five days once or depends upon the water and shrimp quality. The purpose of water exchange is to maintaining water quality and also to stimulate moulting of the shrimp, resulting in acceleration of growth and production. Feed management plays a major role in the shrimp culture. Godrej feed (Godrej Agro Vet feeds, Vijayawada) was used during the entire cycle, distributed manually by using of boat. During the first month after stocking, feeding rates were based on estimated survival and feeding tables and distributed four times per day. After $40^{\text {th }} \mathrm{DOC}$, daily rations were adjusted using feed trays and increased to five times per day thereafter. The use of feed trays is extremely important in the control of feeding. They provide information regarding the feed consumption, the health and survival of the shrimp and also the condition of the pond bottom. It is also necessary to use a lift net to find out if the amount of feed is given properly. If the shrimp not consumed all the feed within the given time, we have to reduce the feed to prevent over feeding. Left over feed can cause the pond bottom to decay and water becomes deteriorated easily, the shrimp will be weak and stressed. They will also avoid feeding and easily get sick and eventually die.During sample time a cast net was used for capture and measures the growth rate of shrimps. The first sampling was taken after $40^{\text {th }}$ days of culture and number of individuals and the average body weights were recorded in each sampling. Five hauls were made in randomly selected areas of each pond. Healthiness, survival rate, Average Body weight (ABW) and Average daily growth (ADG) of the animals was estimated. Sampling was regularly performed every ten days until harvest. At the harvesting period a bag net was fitted on outlet canal with a 20 numbers mesh of width $1 \mathrm{~m}$ and length of $4 \mathrm{~m}$. The water level in the ponds was reduced from $1 \mathrm{~m}$ to $60 \mathrm{~cm}$ and then out let was opened and shrimp were caught and collected.

\section{RESULTS}

The water quality parameters in the culture ponds are displayed in the Table 1 . The salinity was recorded maximum $28 \mathrm{ppt}$ and minimum $12 \mathrm{ppt}$ for both high and low density ponds. The average $\mathrm{pH}$ was in between 7.6 to 8.2. The dissolved oxygen was ranged between 3.6 to $6.5 \mathrm{ppm}$. The survival was good in both low and high density ponds because in the nursery period Cyclop-eeze feed used as an extra feed. The survival rate in low density ponds was $82 \%$ and high density ponds was $64 \%$. Maximum growth was observed in the low density ponds during each sampling interval and by the end of the experiment. In hapa culture SHG infected postlarvae was gained $98.7 \%$ survival in low stocking density and $87.2 \%$ in high stocking density (Table 2). Average weight gained for the shrimps that were stocked with low density ponds was approximately $22 \%$ greater than that of the high density ponds (Table 6). Maximum net profit was obtained from low density ponds (Rs.57,691) and minimum was in high density ponds (Rs.1,82,201). Average cost gained for the shrimps that were stocked with low density ponds was approximately $34 \%$ greater than that of the high density ponds (Table 7).

\section{Discussion}

There has been a considerable increase in the culture of brackish water shrimp due to its taste, market demand both national and international markets. In order to prevent many problems due to shrimp culture, sustainable shrimp farming is the need of the hour. Ideal pond size for shrimp culture was 1 or less than 1 ha (Boyd, 2001; Ramanathan et al., 2005). In the present investigation also 6 ponds were used for shrimp culture and each pond size was 0.5 ha. Even though shrimps are bottom dwelling organisms, the depth and volume of water in a pond has certain physical and biological consequences. The volumes of water behave like a buffer, which prevents weather fluctuations from influencing the environment in which shrimp lives. The ideal water depth is between 1.0 to $1.5 \mathrm{~m}$ depending upon the stage of culture. It is recommended that a minimum depth of $1 \mathrm{~m}$ is maintained at operational level. In the present study $120 \mathrm{~cm}$ water level was maintained in all ponds throughout the culture period. The optimum stocking density of seeds in a pond determined in accordance with the production capacity of the pond and the culture system, which included the soil and water quality, food availability and seasonal variations, target production and farmers experience (Ramanathan et al., 2005). The stocking density in between 10 to20 PLs $/ \mathrm{m}^{2}$ is ideal for successful shrimp farms (Ramanathan et al., 2005). In the present study the seeds were stocked at the stocking density of $9 / \mathrm{m} 2$ in three ponds and also $18 / \mathrm{m}^{2}$ in the remaining three ponds. The maintenance of good water quality is essential for optimum growth and survival of shrimps. The levels of physical, chemical and biological parameters control the quality of pond waters. The level of metabolites in pond water can have an adverse effect on the growth. Good water quality is characterized 
by adequate oxygen and limited level of metabolites. Excess feed, faecal matter and metabolites will exert tremendous influence on the water quality of the shrimp ponds. Hence critical water quality parameters are to be monitored carefully as adverse conditions may be disastrous effect on the growing shrimps (Ramanathan et al., 2005). Salinity is important parameters to control growth and survival of shrimps. Even though P. monodon is euryhaline animals it is com fortable when exposed to optimum salinity. At high salinity the shrimps will grow slow but they are healthy and resistance to diseases. If the salinity is low the shell will be weak and prone to diseases. The salinity of the present study was maintained 12 to $28 \mathrm{ppt}$ in all ponds (Table 1). Muthu (1980), Karthikeyan (1994) and Soundarapandian \& Gunalan (2008) recommended a salinity range of 10 to 35 ppt was ideal for P. monodon culture. While Chanratchakool et al. (1994) and Rajalakshmi (1980) maintained the salinity of 10 to30 ppt and 15 to $20 \mathrm{ppt}$ respectively. Chen (1980) opined that salinity ranges of 15 to20 ppt are optimal for culture of P.monodon. There are few reports (Shivappa and Hambry, 1997; Ramakrishnareddy, 2000; Collins \& Russel, 2003), which stated that P. monodon adapted quite well in freshwater conditions also because of its wide range of salinity tolerance. Dissolved oxygen plays an important role on growth and production through its direct effect on feed consumption and maturation. Oxygen affects the solubility and availability of many nutrients. Low levels of dissolved oxygen can cause damages in oxidation state of substances from the oxidized to the reduced form. Lack of dissolved oxygen is directly harmful to shrimps and causes a substantial increase in the level of toxic metabolites. Low-level of oxygen tension hampers metabolic performances in shrimp and can reduce growth and moulting and cause mortality (Gilles, 2001). The dissolved oxygen in all the culture ponds in the present study was ranging between 3.6 to $6.5 \mathrm{ppm}$ (Table, 1). pH is one of the vital environmental characteristics, which decides the survival and growth of shrimps under culture; it also affects the metabolism and other physiological process of shrimps. The optimum range of $\mathrm{pH} 6.8$ to 8.7 should be maintained for maximum growth and production (Ramanathan et al., 2005). In the present study $\mathrm{pH}$ was maintained in between 7.6 to 8.2 for the culture ponds. Saha et al. (1999) noticed the $\mathrm{pH}$ of 8.11 to 8.67 in low saline ponds. Ramakrishnareddy (2000) was recommended pH of 7.5 to 8.5 for P.monodon culture. The $\mathrm{pH}$ of pond water is influenced by many factors, including $\mathrm{pH}$ of source waters and acidity of bottom soil and shrimp culture inputs and biological activity. The most common cause of low $\mathrm{pH}$ in water is acidic bottom soil, liming can be used to reduce soil acidity. In most common cause of high $\mathrm{pH}$ is high rate of photosynthesis by dense phytoplankton blooms. When $\mathrm{pH}$ is high water exchange will be better choice (Boyd, 2001). Water temperature is probably the most important environmental variables in shrimp cultures, because it directly affects metabolism, oxygen consumption, growth, moulting and survival. In general, a sudden change of temperature affects the shrimp immune system. The optimum range of temperature for the black tiger shrimp is between 28 to $30^{\circ} \mathrm{C}$ (Ramanathan et al., 2005). The temperature in the present study was 26 to $30^{\circ} \mathrm{C}$ and the low temperature $25{ }^{\circ} \mathrm{C}$ was observed due to cloudy weather (Table 1). The optimum range of temperature of $P$. monodon was between 26 to $33{ }^{\circ} \mathrm{C}$ and temperature range of 28 to $33^{\circ} \mathrm{C}$ supports normal growth (Jaganmohan and Prasad, 2010) as observed in the present study. The transparency is mainly depends on the presence of phytoplankton. The secchi disc reading should be maintained in between 30 to $40 \mathrm{~cm}$ is good for culture operation (MEPEDA, 2006; Jaideep et al., 2011). The optimum range of secchi disc reading is between 30 to 60 $\mathrm{cm}$ to the juvenile stage and between 25 to $40 \mathrm{~cm}$ to the sub adult and final stage. The transparency of the present study is 25 to $45 \mathrm{~cm}$ (Table 4). Ramakrishnareddy (2000) also observed similar transparencies ( 35 to 55 $\mathrm{cm}$ ) for his study. The reading less than $30 \mathrm{~cm}$ mean that the phytoplankton density is high. If it is more than 40 $\mathrm{cm}$ indicates, low population of phytoplankton. For the growth of phytoplankton adequate quality of sunlight is needed. Due to low intensity of light during the culture period, the plankton bloom was less. Hence, the transparency was more.

Feed is one of the essential inputs in shrimp production and increase profits. Feed management is highly subjective, as feed consumption cannot be directly observed. In the present study Godrej feeds was used for all ponds and the amount was followed as per feed chat. Maximum amount of feed was given to high density ponds. The FCR for low density ponds w ere 1.3 and high density ponds were 1.8. Average Indian cultured food conversion ratios were varying in between 1.5 to 1.7 (Paul Raj, 1998; MPEDA, 2006). Cheekati (1995) observed the food conversion ratios were varying from 1.50 to 1.55 when microencapsulated diets are used. Saha et al. (1999) observed that the food conversion ratios of 1.31 to 1.58 in low saline ponds and 1.35 and 1.68 in high saline ponds. Ramakrishnareddy (2000) observed FCR of 1.58 for his study. Periodic sampling is very vital for successful shrimp culture. It is recommended to do weekly or fortnightly sampling to check the health condition as well as to estimate the growth of shrimps. Sampling also helps to know the average weight and this would help in estimating the total biomass in the pond for better-feed management. Growth of shrimps depends mainly on pond water quality and effective management of feeding. Cyclop-eeze was used as a feed in the present study played a major role for the better growth of shrimps (Table 4 to 6). It is observed that growth rate of shrimps in the present study is rapidly increasing after DOC 40 in all ponds due to accurate feed manipulation by sampling. In the present study higher survival $(82 \%)$ was recorded in the low density ponds and lower survival (64\%) was achieved in the high density ponds. Krantz \& Norris (1975) stated that survival rates of 60 to $80 \%$ are to be expected for P. monodon under suitable rearing conditions. It was achieved because the 
stocking density of 5, 000 to 8,000 PLs/ha. In the present study also totally 50,000 PLs for low density ponds and 90,000 pls were stocked for high density ponds. Ramakrishnareddy (2000) got $76 \%$ survival and average body weight of $35.22 \mathrm{~g}$. According to him $70-80 \%$ survival is possible if the idle conditions are maintained for P. monodon. In the present study the average body weight of the shrimps were calculated for low and high density ponds were 40.5 and $32.6 \mathrm{~g}$ respectively (Table 3 ). The size of culture shrimps, market price and moulting percentage of shrimps plays a vital role in fixing the harvesting so that timely harvest is very essential in aquaculture system. The average production from low density (A1, A2 and A3) ponds were $1494 \mathrm{~kg}$ and the average body weight is calculated as $40.5 \mathrm{~g}$, but in the high density ponds (B1, B2 and B3) it was $1878 \mathrm{~kg}$ and average body weight was $32.6 \mathrm{~g}$ only (Table 5). So it is confirmed that $8-10 / \mathrm{m}^{2}$ is an ideal stocking density (Jaideep et al, 2011) for the culture of $P$. monodon as evidenced from the high net profit Rs 1,82,201. Based on the above results revealed that the effect of the SHG infected P.monodon postlarvae can be cultured in low stocking densities and harvested as similar to the normal seed provided the best farm management practices are followed by the shrimp farmer. To get this profit, proper nursery stocking, providing of cyclop-eeze feed, water quality management and feed management is essential.

\section{Acknowledgement}

During the present study we are thankful to farm manager Sri. B. Rambabu for providing all facilities for successful completion of this study.

\section{References}

[1] Afrabuddin, S and N. Akter, 2011. Swollen hindgut syndrome (SHG) of tiger shrimp Penaeus monodon larvae. AACL, Bioflux, $4(1)$.

[2] Boyd, C.E., 2001. Water quality standards: pH. The advocate, pp: 42. Chanratchkool, P., J.F. Turunbull and C.C. Limsunean, 1994. Health management in shrimp ponds. Aquatic Health Research Institute, Department of Fisheries, Kasetasart Uniersity, Bankok, pp: 91.

[3] Chanratchkool, P., J.F. Turunbull and C. Limsunean, 1994. Health management in Shrimp ponds. Aquatic Health Research Institute, Department of Fisheries, Kasetasart University, Bankok, pp: 91.

[4] Cheekait, N.G., 1995. Micro-encapsulation applications in aquaculture. Aqua International., pp: 28-29.

[5] Chen, H.C., 1980. Water quality criteria for farming the grass shrimp, Penaeus monodon in : Proceedings of the fist International conference on culture of Penaid prawns/ shrimps, edited by Y, Take, J.H. Primavera and J.A. Liobrea, pp: 165.

[6] Collins, A. and B. Russel, 2003. Inland Prawn farming trail in Australia. Pond study tests Penaeus monodon performance in low salinity ground water. Global aquaculture advocate, pp: 74-75.

[7] Gilles L.M., 2001. Environmental factors affect immune response and resistance in Crustaceans. The advocate, pp: 18.

[8] Jaganmohan, P and Prasad, S. V. 2010. Effect of probiotics on the growth and survival of Penaeus monodon, infected with Swollen Hind Gut (SHG) at post larval stage. World Journal of Fish and Marine Sciences 2(4): 311-316.

[9] Jaideep Kumar, P. Chearan, E and Thampi Sam Raj. 2011. Growth and survival of Swollen Hind Gut (SHG) infected Penaeus monodon (Fabricus, 1798) post larvae, in farm Grow-out system. World Journal of Fish and Marine Sciences 3(3): 190-193.

[10] Karthikeyan, J., 1994. Aquaculture (Shrimp farming) its influence on environment. Technical paper submitted to the seminar Our Environment-Its challenges to development projects. Septem ber, American Society of Civil Engineers, Culcutta, India, pp: 9-10.

[11] Krantz, G.C. and J. N orris, 1975. Proceedings of $6^{\text {th }}$ Annual Workshop, Mariculture Society, Seattle, Washington, 27-31, 6 January, pp: 48-51.

[12] MPEDA, 2006. Media campaign on "Welfare schemes of Central Government" Gopichettipalayam on 27 and 28 of January.

[13] Lavilla-Pitogo, C. R., M. G. Paner and R. D. Travina, 2002. Swollen hindgut syndrome (SHG) in hatchery reared Penaeus monodon postlarvae. Fish Health Section. Asian Fisheries Society, Manila, PP: 151-158.

[14] Muthu, M.S. 1980. Site selection and type of farms for coastal aquaculture of prawns. Proceedings of the Symposium on shrimp farming, Bombay, 16-18 August, Marine Products Export Development Authority, pp: 97-106.

[15] Paul Raj, B.B. 1998. Ecofriendly feed and management system for sustainable shrimp culture. Fisheries World, pp: 13-17.

[16] Rajalakshmi, T., 1980. Manual on brakish water aquaculture, India. Central Inland Fisheries. Research Institute Bulletin, 31: 1126.

[17] Ramakrishnareddy, 2000. Culture of the tiger shrimp Penaeus monodon (Fabricus) in low saline waters. M.Sc., dissertation, Annamalai University, pp: 31.

[18] Ramanathan,N., P. Padmavathy, T. Francis , S. Athithian and N. Selvaranjitham, 2005. Manual on Polyculture of tiger shrimp and carps in freshwater, Tamil Nadu Veterinary and Animal Sciences University, Fisheries College and Research Institute, Thothukudi, pp: 1-161.

[19] Saha, S.B., C. Bhattacharyya, and A. Choudhury, 1999. Preliminary observations on culture of Penaeus monodon in low saline waters. Naga. $22(10): 30-33$.

[20] SEAFDEC/AQD report, 1994. R \& D for Sustainable Aquaculture. Diseases of tiger shrimp. Pp. 30.

[21] Shivappa, R.B. and Hamrey, J.B.1997. Tiger shrimp culture in freshwater, Ifo Fish International, 4(97): 32-36.

[22] Soundarapandian, P. and B. Gunalan, 2008. Recent technology for the survival and production of giant tiger shrimp Penaeus monodon along South East Coast of India. Int. J. Zool. Res., 4 (1): 21-27. 
Effect Of Cyclop-Eeze On Growth And Survival Of Shg (Swollen Hindgut Syndrome) Infected

Table 1: Water quality parameters in culture ponds (both low and high density stocking ponds)

\begin{tabular}{|lc|}
\hline Parameter & Range \\
\hline Temperature $(\mathrm{oC})$ & 26 to 30 \\
Salinity $(\mathrm{ppt})$ & 12 to 28 \\
$\mathrm{pH}(\mathrm{ppm})$ & 7.6 to 8.2 \\
Dissolved oxygen $(\mathrm{ppm})$ & 3.6 to 6.5 \\
Transparency $(\mathrm{cm})$ & 35 to 55 \\
Ammonia & 0.1 to 0.3 \\
\hline
\end{tabular}

Table 2: Growth and survival of P.monodon in Hapa survival in low and high stocking densities

\begin{tabular}{|lcc|}
\hline Parameter & $\begin{array}{c}\text { SHG infected } \\
\text { (low stocking density) }\end{array}$ & $\begin{array}{c}\text { SHG infected } \\
\text { (high stocking density) }\end{array}$ \\
\hline 24 hrs after stocking & $75.4 \pm 0.18$ & $91.5 \pm 0.14$ \\
ABW at harvest & $32.72 \pm 0.45$ & $26.82 \pm 0.25$ \\
Survival at Harvest & $98.71 \pm 1.32$ & $87.2 \pm 0.06$ \\
\hline
\end{tabular}

Table 3: Average weight (g) of P.monodon in low and high density stocking ponds

\begin{tabular}{|c|c|c|}
\hline $\begin{array}{c}\text { Date of culture } \\
\text { (DOC) }\end{array}$ & $\begin{array}{l}\mathbf{A 1}, \mathbf{A} 2, \mathbf{A} 3 \\
\left(9 \text { Pl's/M' } \mathbf{M}^{2}\right)\end{array}$ & $\begin{array}{c}\text { B1, B2, B3 } \\
\left(18 \mathrm{Pl} ' \mathrm{~s} / \mathrm{M}^{2}\right)\end{array}$ \\
\hline 40 & 7.5 & 5.2 \\
\hline 50 & 11.5 & 8.2 \\
\hline 60 & 13.2 & 9.5 \\
\hline 70 & 15.6 & 10.4 \\
\hline 80 & 19.2 & 12.2 \\
\hline 90 & 22.4 & 13.5 \\
\hline 100 & 28.5 & 16.2 \\
\hline 110 & 31.4 & 20.1 \\
\hline 120 & 32.6 & 21.5 \\
\hline 130 & 37.5 & 23.5 \\
\hline 140 & 40.5 & 26.5 \\
\hline 150 & - & 28.4 \\
\hline 160 & - & 30.8 \\
\hline 170 & - & 32.6 \\
\hline
\end{tabular}

Table 4: Dosage of Cyclop-Eeze in low and high stocking density ponds (for one lack seed)

\begin{tabular}{|c|c|c|c|c|}
\hline \multirow{2}{*}{ Pond No } & \multicolumn{4}{|c|}{$\begin{array}{c}\text { Dosage and timing of Cyclop-Eeze fed } \\
\text { (for 1 lack seed) }\end{array}$} \\
\cline { 2 - 5 } & $\mathbf{6 . 0 0}$ & $\mathbf{1 2 . 0 0}$ & $\mathbf{1 8 . 0 0}$ & $\mathbf{2 2 . 0 0}$ \\
\hline A-1 & 80 & 80 & 80 & 80 \\
\hline A-2 & 80 & 80 & 80 & 80 \\
\hline A-3 & 80 & 80 & 80 & 80 \\
\hline B-1 & 100 & 100 & 100 & 100 \\
\hline B-2 & 100 & 100 & 100 & 100 \\
\hline B-3 & 100 & 100 & 100 & 100 \\
\hline
\end{tabular}


Effect Of Cyclop-Eeze On Growth And Survival Of Shg (Swollen Hindgut Syndrome) Infected

Table 5: Dosage of Cyclop-Eeze for the low stocking density ponds (Sugar used as a binder)

\begin{tabular}{|c|c|c|c|c|}
\hline \multirow{2}{*}{$\begin{array}{c}\text { Date of culture } \\
(\mathbf{D O C})\end{array}$} & \multicolumn{4}{|c|}{$\begin{array}{c}\text { Dosage and timing of Cyclop-Eeze fed (for 1 lack seed) } \\
\text { for low stocking density }\end{array}$} \\
\cline { 2 - 5 } & $\mathbf{6 . 0 0}(\mathbf{g} / \mathbf{k g})$ & $\mathbf{1 2 . 0 0}(\mathbf{g} / \mathbf{k g})$ & $\mathbf{1 8 . 0 0}(\mathbf{g} / \mathbf{k g})$ & $\mathbf{2 2 . 0 0}(\mathbf{g} / \mathbf{k g})$ \\
\hline $20-30$ & 10 & - & 10 & 10 \\
\hline $31-40$ & 10 & - & 10 & 10 \\
\hline $41-50$ & - & - & 10 & 10 \\
\hline $51-60$ & 10 & - & - & 10 \\
\hline $61-70$ & 10 & - & - & 10 \\
\hline $71-80$ & - & - & 10 & 10 \\
\hline $81-90$ & - & - & 10 & 10 \\
\hline $91-100$ & 10 & 10 & 10 & 10 \\
\hline $101-110$ & - & 10 & 10 & 10 \\
\hline $111-120$ & - & 10 & 20 & 10 \\
\hline $121-130$ & 10 & 10 & 20 & 10 \\
\hline $131-140$ & 10 & 10 & 20 & \\
\hline
\end{tabular}

Table 6: Dosage of Cyclop-Eeze for the high stocking density ponds (Sugar used as a binder)

\begin{tabular}{|c|c|c|c|c|}
\hline \multirow{2}{*}{$\begin{array}{c}\text { Date of } \\
\text { culture } \\
\text { (DOC) }\end{array}$} & \multicolumn{4}{|c|}{$\begin{array}{c}\text { Dosage and timing of Cyclop-Eeze fed (for 1 lack seed) } \\
\text { for high stocking density }\end{array}$} \\
\cline { 2 - 5 } & $\mathbf{6 . 0 0} \mathbf{~ g / k g}$ & $\mathbf{1 2 . 0 0} \mathbf{g} / \mathbf{k g}$ & $\mathbf{1 8 . 0 0} \mathbf{~ g} / \mathbf{k g}$ & $\mathbf{2 2 . 0 0} \mathbf{g} / \mathbf{k g}$ \\
\hline $20-30$ & 10 & $-\mathbf{c}^{-}$ & 10 & 10 \\
\hline $31-40$ & 10 & - & 10 & 10 \\
\hline $41-50$ & - & - & 10 & 10 \\
\hline $51-60$ & 10 & - & 10 & - \\
\hline $61-70$ & & - & 10 & 10 \\
\hline $71-80$ & 10 & - & - & 10 \\
\hline $81-90$ & 10 & - & - & 10 \\
\hline $91-100$ & - & - & 10 & - \\
\hline $101-110$ & - & 10 & 10 & 20 \\
\hline $111-120$ & 10 & 10 & 20 & 20 \\
\hline $121-130$ & 10 & 10 & 20 & 20 \\
\hline $131-140$ & - & 10 & 20 & 20 \\
\hline $141-150$ & 20 & 10 & 20 & 20 \\
\hline $151-160$ & 20 & 20 & 20 & 20 \\
\hline $161-170$ & 20 & 20 & 20 & \\
\hline
\end{tabular}

Table 7: Average harvest and economics of P.monodon cultured in low and high stocking densities

\begin{tabular}{|l|c|c|}
\hline Particulars & $\begin{array}{c}\text { Pond -A1 } \\
\text { (8 Pl's/m2) }\end{array}$ & $\begin{array}{c}\text { Pond -A2 } \\
(\mathbf{1 5} \text { Pl's/m2) }\end{array}$ \\
\hline Pond area (m2) & 5000 & 5000 \\
\hline Stocking density/m2 & 9 & 18 \\
\hline Initial stock & 45000 & 90000 \\
\hline Average daily growth & 0.325 & 0.216 \\
\hline Culture period (Days) & 140 & 170 \\
\hline Total Production (Kg) & 1494 & 1878 \\
\hline Production (Ton/Ha) & 2989 & 3756 \\
\hline Size of Harvest (g) & 40.5 & 32.6 \\
\hline Survival rate (\%) & 82 & 64 \\
\hline Food intake & 1973 & 3474 \\
\hline FCR & 1.32 & 1.85 \\
\hline Income & 448335 & 516384 \\
\hline Seed cost (Rs) & 67500 & 135000 \\
\hline Total feed cost (Rs) & 98634 & 173693 \\
\hline Other expenses & 100000 & 150000 \\
\hline Net Profit (Rs) & 182201 & 57691 \\
\hline
\end{tabular}

